\title{
ASSESSING THE IMPACT OF RELATIONSHIP QUALITY ON ONLINE ADOPTION
}

\author{
Dr. Renu Aggarwal \\ YMCA, Faridabad \\ and \\ Monica Bhardwaj \\ Fortune Institute of International Business, \\ Plot no 5, Rao Tula Ram Marg,,VasantVihar, Delhi, Delhi, India- 110057
}

\begin{abstract}
Relationships are strongly embedded in Indian culture due to its high-context nature. Because of this, the role of relationship marketing has been advanced in a variety of services viz., banking, retailing, telecom, etc and hence the competition amongst various service providers has increased. Traditionally, relationship management used to be personal interaction based phenomenon but with IT as an enabler for online channels, the need for creating and growing relationships have transpired in a big way. With the advent of technological changes in the business environment, customers are seeking better alternatives to reduce the frequency of visiting the bank branch physically and are relying more on the virtual mode for transacting. Hence, banks and other service organizations are strongly focussing on the digital (online) channels for facilitating monetary transactions and hence gaining competitive advantage. In the virtual mode, the concept of relationships appears to be unrealistic due to the absence of human interface. However, significant studies have been conducted in this regard which focus on the influence of relationship quality factors viz., trust, commitment, satisfaction, etc. towards adopting the online channel for carrying out financial transactions. Relationship quality focuses on evaluating the strength of relationships, which affects customer loyalty. There exists a dearth of such significant studies in the Indian context. The present research will focus on bridging this gap in the literature. This paper will follow a causal research design for empirically analysing the impact of $R Q$ factors towards adopting online mode for banking transactions. It will also investigate the future intentions of the customers toward using the online channels for carrying out financial transactions.
\end{abstract}

\section{Keywords}

Relationship Quality, Online, Adoption, India

\section{INTRODUCTION}

Relationship marketing in the context of banking aims at establishing and maintaining long-term relationships with the customers (Ritter, 1993). The task of relationship becomes more challenging for online transactions (Mukherjee and Nath, 2003). In order to understand this challenge in a more sophisticated manner an assessment of the relationship strength is required. This can be judged using Relationship Quality (RQ) measures.

Banking industry has been strongly enabled by the internet, which makes it convenient for the consumers to transact without physically visiting the bank.Commonly used banking operations by the customers via online medium include access to account information, funds transfer and bill payment. E-banking involves using internet technologies viz., internet, ATMs, mobile phones,etc. DOI : 10.14810/ijbiss.2016.5101 
for carrying out banking transactions (Abbasnejad, 2006 cited by Esmaeili et al, 2013). E-banking systems communicate customers about the banks' efforts at three levels viz., notification, communication, and transaction (Ghane et al., 2010). Consumers are using internet banking for online shopping, mobile recharges, travel booking, movie ticket booking, etc.Consumers are benefitted in terms of easy access to their account, which can be controlled by them without any intervention/help from the bank employees and hence the banking consumers can make prompt financial decisions. In other words, online banking system is a self-service technology interface Meuteret al (2000).

An important and challenging issue for the banks is the perceived security, which is perhaps due to the absence of bank employees and hence the banks are required to look at initiatives for developing online banking relationships and hence shall look at strengthening the online relationship quality (Warrington et al, 2000). Banks are expected to inculcate trust in the relationships such that the online banking is promoted which further looks at building customer loyalty. The importance of trust is at the paramount level due to the complexities arising from the virtual environment (Mukherjee and Nath,2003).

Interestingly, trust is understood as the key factor, which is one of the components of RQ. The other important factors include commitment and satisfaction. These are discussed in detail under the review of literature section.

The popularity of online banking has propelled since mid 1990s across the globe especially among the developed countries (Pikkarainenet al., 2004). The rate of penetration for online banking has risen immensely in the last few years. In 2012, the total number of internet users were 137 million which is expected to rise to somewhere in the range of 330 million to 370 million (Internet World Stats, 2010; McKinsey Digital Consumer Research, 2013). In addition, the digital maturity index suggests that banking industry in India is at the starting stage of digital maturity (Mckinsey Analysis, 2013) while industries like personal computing and travel have reached the digital acceleration levels in India. According to the McKinsey Digital Consumer Survey 2012, the penetration for digital high-value consumers is $24 \%$ and online banking is used 0.19 times per week, while for overall consumers it is $7 \%$, who use online banking 0.02 times per week. It is worth noting that the purchases made by the digital high-value consumers is just $1 \%$ while researching for the same and making final decision for purchase score $64 \%$ and $42 \%$ respectively thereby suggesting the lack of trust in the virtual medium. According to Mckinsey's (2012) article on the impact of internet on India, the online payment system needs to be strengthened for which the Indian banking consumers exhibit low levels of trust and confidence. However, on the positive note, India still has a good scope for improvement in online payment systems and internet readiness, which is also mentioned in the same report.

Therefore, it is important to evaluate the factors, which significantly affect the consumer's intention to adopt the online medium for banking and payments and their plan to continue with the online banking system in future.In addition to this, the online technology interface provided by the bank has been evolving over the years and hence suggest the need for research towards the adoption of online banking which is aimed at enhancing the customer intentions (Loureiro et al., 2014). This study attempts to integrate RQ and online banking adoption thereby extending the current state of knowledge. 
To address this, following research questions are put forward-

RQ1: Which relationship quality factors are the significant influencers of online banking adoption?

RQ2: How do relationship quality factors influence the consumer's adoption process towards online banking?

The next section of the paper discusses the review of literature in which the factors pertaining to RQ viz., trust, commitment and satisfaction are reviewed. This is followed by the methodology section wherein the data collection method and the survey instrument along with scale development are discussed. Next, analysis of data is presented along with the structural model. This is followed by the discussion and managerial implications.

\section{REVIEW OF LITERATURE}

It is well understood in the literature that much of the research pertaining to online adoption refers to the Technology Acceptance Model (TAM) and Theory of Reasoned Action (TRA). However, there have been many variations in the conceptualization and application of the model, which has resulted into various modified versions. In addition, the elusive nature of the online environment calls for more focus on the human factors, which ponder on relationships and hence the conceptualization of RQ towards its influence on adoption intentions holds importance.

The consideration of RQ has been different across various studies in a very creative manner thereby carving out different dimensions. Trust and Satisfaction have been widely accepted however, several researches also consider Commitment as the key factor comprising RQ (Johnson et al., 2004). Initially, the research by Crosby et al (1990) discussed trust and satisfaction as the antecedents of RQ while Wong and Sohal(2002) contributed commitment as the other dimensions but still as the antecedent to RQ. However, there are several research works, which consider these factors as dimensions of RQ and not as antecedents. These include the works of Storbacka et al (1994), Henning-Thurau and Klee (1997), Dorsch et al (1998), Smith(1998), Baker et al (1999), Garbarino and Johnson (1999), Lang and Colgate (2003), Walter et al (2003), Van Bruggen et al (2005), Ulaga and Eggert (2006), Leonidou et al (2006), Carr (2006). However, only the work of Lang and Colgate (2003) focus on banks and more specifically the online banking. The need for a fresh research perspective is expected which considers these three dimensions, which have been among the more popular RQ dimensions in the extant literature. These three main RQ factors are discussed in the following paragraphs along with a focus towards the online adoption.

\subsection{Trust}

Trust is the confidence exhibited by the buyer in the seller's future performance. Trust is a key construct of RQ and a favourably perceived future performance results in high level of RQ and hence positively influences customer loyalty (Zhang et al., 2011).Trust holds greater importance in the online environment in relation to the offline-banking environment (Ratnasingham, 1998).

Trust is related with sub-factors viz., benevolence, competence, integrity, predictability, etc. which is based on customer's beliefs about the quality of services provided by the service 
provider in online contexts (Gefen et al.,2003). Yee and Faziharudean (2010) discussed, through review of literature, how trust influences customer loyalty. Cyr et al (2007) found a direct and positive association between trust and loyalty in the context of e-services while the same was supported by Lin and Wang (2006) in the m-commerce context. In addition, Floh and Treiblmaier (2006) discussed trust and satisfaction apart from website quality as antecedents to customer loyalty in the online banking context.Yee and Faziharudean (2010) empirically investigated the impact of trust along with other factors on customer loyalty and found trust significantly influencing the customer loyalty in Malaysian online banking environment. Kim et al (2013) studied the mediating role of trust on the usage intentions in online shopping context.

Yousafzai et al (2009)found that trust is an antecedent of behavioural intention and holds a multidimensional position in adoption to internet banking. Moreover, online banking is conditional to evoking of trust in the consumer's mind, which depends on the ability of the bank. Trust also had significant and positive effect on internet banking adoption in the Vietnamese context (Chong et al, 2010). Some research works, which focus on TAM, also included trust in the structural model while evaluating the adoption intentions. Trust was considered as an antecedent to PU and PEOU dimensions of TAM and found that the trust has positive influence on both these dimensions (Erikssonet al, 2005). Also, PU and PEOU in turn influence the attitude towards online banking (Chiou and Shen, 2012). Suh and Han (2002) found that trust significantly influences customer's attitude towards adoption to online banking.

Suh and Han (2002) found trust as a key factor in elucidating customer attitude towards the adoption of online banking (Suh and Han, 2002). It is the attitude, which along with trust and PU influences online banking usage intentions. It is worth noting that attitude towards adoption is also understood as acceptance which is an antecedent to adoption intentions which in-turn might influence continuance usage intentions. Contrary to this,Kesharwani and Bisht (2012) found trust as an impediment towards online banking transactions in the Indian context when used as an extra dimension to TAM.

\subsection{Commitment}

In the context of consumer behaviour,commitment is a long-term wish for consumer to maintain the relationships (Moorman et al., 1993). Commitment can take three forms viz, attitudinal, instrumental and temporal (Gundlach et al., 1995) and also commitment is revealed in adoption of online banking (Rexha et al., 2003). It is also affects behaviour and attitude in a positive manner (Johnson et al., 2006). In fact, behaviour and attitude are the pointers to loyalty (Chiu et al., 2009). Behaviour can be elaborated as intention to purchase and intention to adopt in the online context. Attitude has been however understood differently in the literature where Chiu et al(2009) discuss it as willingness to recommend while in TAM it is an antecedent to intention to adopt.

Looking into the RQ literature it is seen that commitment has found place as a dimension of RQ in different service industry settings. These include electronic products retailing (Heenig-Thurau, 2000), apparel retailing (De Wulf et al, 2003; De Cannie're et al. 2009), travel agency (Moliner et al, 2007; Beatson et al, 2008). Studies pertaining to the banking industry involving the conceptualization of commitment as a dimension of RQ include the works of Lang and Colgate (2003) and Ndubisi (2007) and both these studies focus more on the intangible aspects with the former focussing on the online activities. 


\subsection{Satisfaction}

Satisfaction holds a great deal of importance in the online context (Nusair and Kandampully, 2008).An evaluation of seller'sperformance by the buyer results into the level of satisfaction. In addition, the confirmation or disconfirmation from the expectation of the consumers is another conceptualization of satisfaction(Hennig-Thurau and Hansen, 2000) which arises from expectancy-disconfirmation (Oliver, 1981). However, this theory has limitations due to the lack of understanding by the customers about their expectations especially owing to the complexities of the online environment (Allagui and Temessek, 2004). This calls for measuring satisfaction through customer opinions which is accumulated together to provide a measure of overall satisfaction based on a holistic experience (Garbarino and Johnson, 1999).

For online banking environments it is the online contact with the customers over the period of time, which defines satisfaction (Liang et al,2008) which comes from the interactive online interfaces provided for the customers (Allagui and Temessek, 2004).

A high level of RQ is a function of a high level of satisfaction. Satisfaction being a construct of RQ is highly likely in increasing consumer loyalty (Zhang et al, 2011). According to Mols (1998), online banking environment provides more satisfaction and satisfaction with the existing offering would provide more scope for adapting to the online banking channels. Therefore, past performance acts as an assurance of future performance and hence adoption becomes imminent as it is an additional benefit and more convenient due to the deployment of the technology (Rexha, 2003). In addition, in the context of banking, loyalty is key issue and hence customer satisfaction requires monitoring (Aurier and N'Goala, 2010) in order to achieve a high level of RQ.

\subsection{Attitude}

Situation of risk and uncertainty can be reduced by the involvement of trust (Mayer et al., 1995). Such challenging situations are common in the context of online banking. An increase in trust would result into positive attitude towards the online banking and hence would influence the intention to adopt the online mode for carrying out banking transactions. This point has also been reiterated by Jarvenpaa et al (1999) in the context of an internet store and also in the context of online banking (Liu et al, 2005). In the present study, the authors also contemplate that satisfaction and commitment also influence the attitude in a similar manner.

\subsection{Continuance Usage Intention}

Continuance usage intention is related with the loyal behaviour of the customers towards the online banking. This is connected with continuing the relationship in future and not dropping it. Sometimes this phenomenon is also referred as relational continuity. Satisfaction is understood to be a key predictor of relational continuity (Leuthesser and Kohli, 1995). It is highly expected that relationships between the bank and the customer should develop with time which is contingent to high satisfaction levels due to which the customers are loyal and don't switch their service providers (Mols, 1999).

A variety of researches exist on online adoption related to banking and other e-commerce environments, which also include influence of RQ factors on intention to adopt online medium for aforementioned situations.A holistic perspective on the key RQ factors exhibiting their 
influence on online adoption needs profound exploration and analysis. Trust, commitment and satisfaction have been discussed under various research works sometimes together but in most cases the three dimensions did not appear together for the purpose of evaluation of their consequences towards online adoption. For the present study, Trust Commitment and Satisfaction are the three factors considered which constitute RQ. In other words, the concept of RQ in the online context has not been widely discussed in a holistic manner. Brun et al (2014) work is perhaps the first significant study, which discusses online RQ comprising of trust, commitment and satisfaction. In addition, Rajaobelina et al (2013) have also included the very same three dimensions of RQ for classifying the online banking customers.

\section{MeTHODS}

\subsection{Sample and Data Collection}

Data was collected from the youth using mall-intercept method from various malls of Delhi-NCR. In addition, students from selected colleges in the region were also targeted for data collection. The students selected were either registered for undergraduate or postgraduate courses and both were mainly from the management streams. Other respondents who were contacted through the mall intercept method were mostly the working professionals. Mall intercept method has been found useful in various studies (O'Cass andGrace, 2008) and also in Indian context (Prasad and Aryasri, 2011, Tripathi and Dave, 2013). A qualifier question was included in the survey instrument to ascertain that the respondents were either casual or frequent users of online banking while at the same time non-users were excluded from the analysis. About 1000 respondents were contact, which resulted into 466 usable questionnaires for further analysis thereby giving a response rate of about $46 \%$. The low response rate is quite usual in survey responses in Indian context especially among the youth who are at times casual users of the service.

\subsection{Instruments and Measures}

The scale items for the three RQ factors along with attitude, adoption intention and continuance usage intentions were extracted from the literature. Attitude towards adoption and behavioural intention were culled from the study by Taylor and Todd (1995) with some modifications. The items for trust, commitment, satisfaction and continuance usage intention were extracted and adapted from the work of Liang et al (2012)

\subsection{Hypothesis}

Based on the review of literature the following hypothesis are proposed -

H1: Trust directly and positively influences Attitude towards Adoption of online banking

H2: Commitment directly and positively influences Attitude towards Adoption of online banking

H3: Satisfaction directly and positively influences Attitude towards Adoption of online banking

H4: Attitude towards Adoption directly and positively influences Intention to Adopt online banking 
H5: Intention to Adopt online banking directly and positively influences Continuance Usage Intention

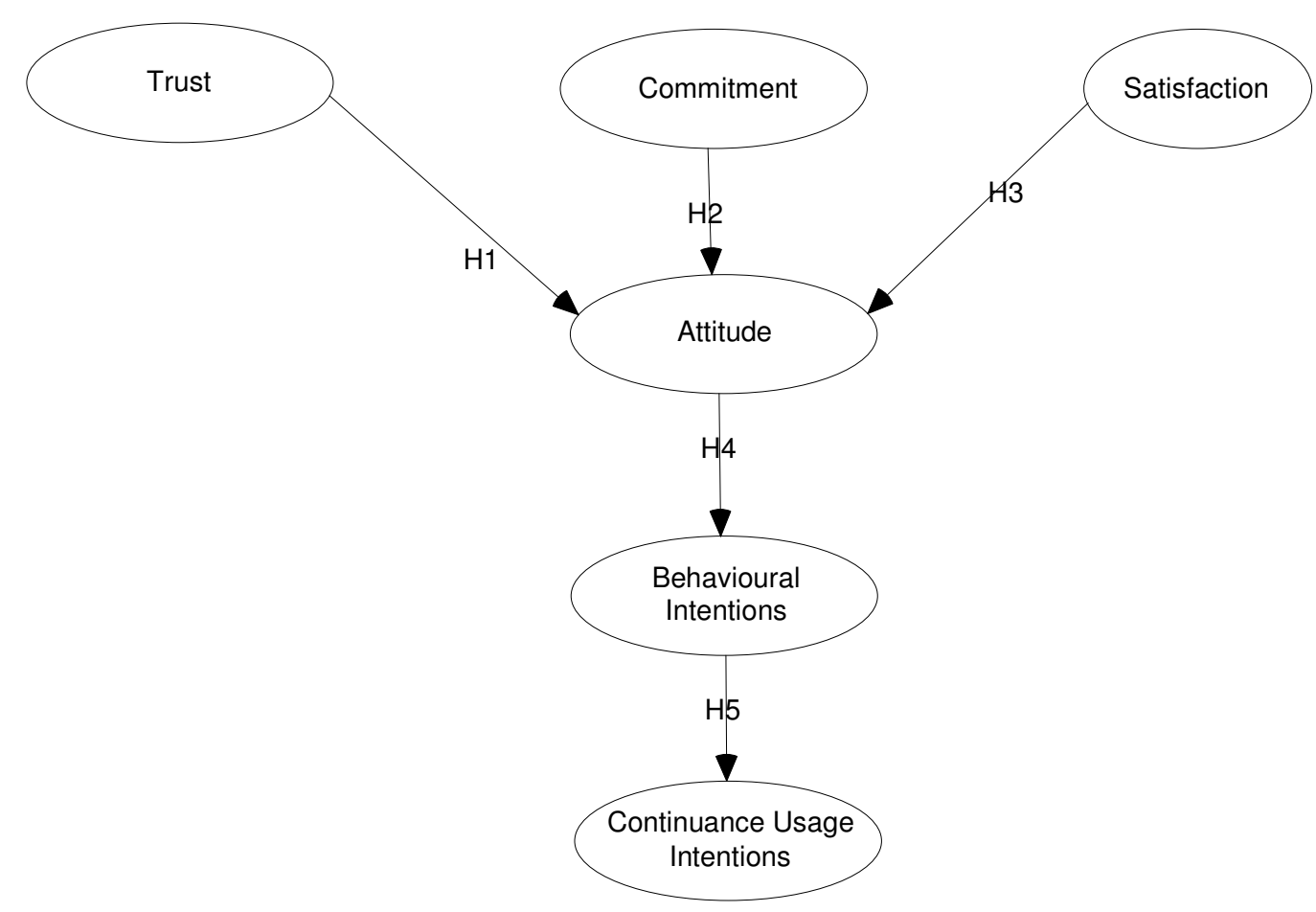

Figure 1: Structural model

\section{ANALYSIS AND DISCUSSION}

First, an Exploratory Factor Analysis was conducted using SPSS for all the variables. The KMO measure was 0.901 and was found significant. The communalities score were all above 0.50 and the total variance extracted was $74 \%$ resulting into six factors. The reliability scores were measured through Cronbach's alpha.

Then the measurement model was evaluated using CFA through AMOS software first for the RQ factors only and then for the whole model together. For the RQ factors only the model fit was found within the acceptable levels with $\mathrm{CMIN} / \mathrm{DF}=2.314, \mathrm{RMR}=0.061, \mathrm{GFI}=0.951, \mathrm{CFI}=0.981$, RMSEA $=0.075$. All items loaded significantly on their respective constructs. Next, CFA was subjected on RQ factors along with attitude towards adoption, intention to adopt and continuance intention. In this case, all the items loaded significantly on their respective dimensions. The model fit was acceptable with $\mathrm{CMIN} / \mathrm{DF}=2.529, \mathrm{RMR}=0.053, \mathrm{GFI}=0.908, \mathrm{CFI}=0.948$, RMSEA $=0.051$. 


\subsection{Scale Reliability}

All the latent constructs show signs of high reliability with Cronbach's Alpha $>0.70$ (Hair et al., 2006) and hence the scale is reliable. In addition, composite reliability and average variance extracted scores are taken for all the RQ factors and for the dependent constructs. These are provided in the Table \# 1.Composite reliability obtained for all the latent variables is greater than 0.70 and hence it crosses the minimum acceptable values (Carmines and Zeller, 1988).

AVE for each factor is greater than 0.5 and hence it is above the minimum acceptable values (Fornell and Larcker, 1981).

\subsection{Construct Validity}

It measures the level to which an observed variable measures the unobserved factors for which they are created. It includes face validity, convergent validity and discriminant validity. Face validity is established by extracting the scale items from the extant literature and the same have been adjusted to fit with the present study.

Convergent validity was established by investigating the factor loadings and AVE. All the factor loadings (or standardized estimates) were significant at $\mathrm{p}<0.001$. Reliability scores were preestablished and were all greater than 0.7 .

All these estimates were higher than 0.7. AVE figures were all greater than 0.50. In addition, AVE was greater than square of the inter-construct correlation. Hence, discriminant validity was established.

\subsection{Testing the Structural model}

The structural model provides an adequate fit with $\mathrm{CMIN} / \mathrm{DF}=3.279, \mathrm{RMR}=0.057, \mathrm{GFI}=0.905$, $\mathrm{CFI}=0.918, \mathrm{RMSEA}=0.059$. The hypotheses results are provided in Table \#2. Except for H2, which is aimed at testing the influence of commitment onattitude towards adopting online banking, all other hypotheses are significant at $\mathrm{p}<0.001$. Results indicate that trust and satisfaction directly and positively influence attitude towards adoption of online banking, which in turn directly and positively influence Intention towards online adoption, which further directly and positively influences intention to continue the online banking usage in future.

Table\# 1: Measurement model statistics

\begin{tabular}{lllll}
\hline Constructs & $\begin{array}{l}\text { Measurement } \\
\text { Items }\end{array}$ & Estimate & AVE & CR \\
\hline \multirow{3}{*}{ Trust } & Trust1 & 0.745 & & \\
& Trust2 & 0.918 & 0.730 & 0.889 \\
& Trust3 & 0.890 & & \\
Commitment & Commitment1 & 0.829 & 0.697 & 0.889 \\
& Commitment2 & 0.885 & &
\end{tabular}




\begin{tabular}{lllll} 
& Commitment3 & 0.787 & & \\
Satisfaction & Satisfaction1 & 0.948 & & \\
& Satisfaction2 & 0.879 & 0.839 & 0.940 \\
& Satisfaction3 & 0.919 & & \\
& Adoption3 & 0.918 & & \\
Attitude & Adoption2 & 0.910 & 0.813 & 0.929 \\
& Adoption1 & 0.877 & & \\
Behavioural & B_Int1 & 0.763 & & \\
Intentions & B_Int2 & 0.941 & 0.759 & 0.903 \\
& B_Int3 & 0.899 & & \\
Continuance & CU_Int1 & 0.873 & & \\
Usage & CU_Int2 & 0.834 & 0.692 & 0.871 \\
& CU_Int3 & 0.786 & & \\
\hline
\end{tabular}

Table \#2: Hypothesis testing

\begin{tabular}{|c|c|c|c|c|c|c|}
\hline Hypotheses & \multicolumn{3}{|c|}{ Hypothesised Paths } & \multirow{2}{*}{$\begin{array}{l}\begin{array}{c}\text { Standardised } \\
\text { Path Co- } \\
\text { efficients }\end{array} \\
0.417\end{array}$} & \multirow{2}{*}{$\begin{array}{c}\begin{array}{c}\text { p- } \\
\text { value }\end{array} \\
* * *\end{array}$} & \multirow{2}{*}{\begin{tabular}{l}
\multicolumn{1}{c}{ Results } \\
Hypothesis \\
Supported
\end{tabular}} \\
\hline H1 & Adoption & $<---$ & Trust & & & \\
\hline $\mathrm{H} 2$ & Adoption & $<---$ & Commitment & -0.036 & 0.671 & $\begin{array}{l}\text { Hypothesis } \\
\text { Not } \\
\text { Supported }\end{array}$ \\
\hline $\mathrm{H} 3$ & Adoption & $<---$ & Satisfaction & 0.393 & $* * *$ & $\begin{array}{l}\text { Hypothesis } \\
\text { Supported }\end{array}$ \\
\hline $\mathrm{H} 4$ & $\mathrm{BI}$ & $<---$ & Adoption & 0.749 & $* * *$ & $\begin{array}{l}\text { Hypothesis } \\
\text { Supported }\end{array}$ \\
\hline H5 & CUI & $<---$ & $\mathrm{BI}$ & 0.764 & $* * *$ & $\begin{array}{l}\text { Hypothesis } \\
\text { Supported }\end{array}$ \\
\hline
\end{tabular}

\section{DISCUSSION AND MANAGERIAL IMPLICATIONS}

The present study is aimed at testing how relationship quality can influence the adoption of online banking by the customers. Insights are gained into the key relationship quality factors, which are identified and validated using the CFA approach. These dimensions can be used by the managers 
to understand the consumer behaviour related to online adoption by the bank customers in the Indian context where the penetration levels of online banking are limited despite a relatively large number of internet users. These factors also bring forward a very important aspect of decisionmaking process, which comes from attitude towards adoption, which is influenced, by trust and satisfaction. Attitude acts an influencer to behavioural intention to adopt online mode for banking. The difference between attitude and intention to adopt is critical but the managerial understanding about the online adoption process is important at one-step further. The intention to adopt might be casual but if the experience werepositive, it would help in adopting online mode for banking more regularly. This focus is necessary for the banks, as online mode is more cost effective than other modes for transactions.

\section{LIMITATIONS AND SCOPE FOR FURTHER RESEARCH}

The current study is limited in its geographical scope of Delhi-NCR, which shall not be considered as a reference for understanding the consumer behaviour for the whole country. In addition, more RQ factors can be derived from the literature, which might help in expanding the academic horizon in the context of online banking adoption. There might be a possibility of a second order constructs particularly comprising of trust and satisfaction especially in the case of online environments (Zhang et al., 2011). Further research can also be conducted regarding the transition from internet banking adoption to mobile banking adoption.

\section{REFERENCES}

1. Allagui, A. and Temessek, A. (2004). Testing an e-loyalty conceptual framework. Journal of EBusiness, 4(1), 44-56.

2. Aurier, P., \&N'Goala, G. (2010). The differing and mediating roles of trust and relationship commitment in service relationship maintenance and development. Journal of the Academy of Marketing Science, 38(3), 303-325.

3. Baker, T. L., Simpson, P. M., \&Siguaw, J. A. (1999). The impact of suppliers' perceptions of reseller market orientation on key relationship constructs.Journal of the Academy of Marketing Science, 27(1), 50-57.

4. Beatson, A., Lings, I., \&Gudergan, S. (2008). Employee behaviour and relationship quality: impact on customers. The Service Industries Journal,28(2), 211-223.

5. Brun, I., Rajaobelina, L., \& Line, R. (2014). Online relationship quality: scale development and initial testing. International Journal of Bank Marketing, 32(1), 5-27.

6. Carmines, E.G. and Zeller, R.A. (1988). Reliability and Validity Assessment, Sage, Beverly Hills, CA.

7. Carr, C. L. (2006). Reciprocity: the golden rule of IS-user service relationship quality and cooperation. Communications of the ACM, 49(6), 77-83.

8. Chiou, J. S., \&Shen, C. C. (2012). The antecedents of online financial service adoption: the impact of physical banking services on Internet banking acceptance. Behaviour\& Information Technology, 31(9), 859-871.

9. Chiu, C. M., Lin, H. Y., Sun, S. Y., \& Hsu, M. H. (2009). Understanding customers' loyalty intentions towards online shopping: an integration of technology acceptance model and fairness theory. Behaviour\& Information Technology, 28(4), 347-360.

10. Chong, A. Y. L., Ooi, K. B., Lin, B., \& Tan, B. I. (2010). Online banking adoption: an empirical analysis. International Journal of Bank Marketing, 28(4), 267-287.

11. Crosby, L. A., Evans, K. R., \& Cowles, D. (1990). Relationship quality in services selling: An interpersonal influence perspective. The Journal of Marketing, 54(3), 68-81.

12. Cyr, D., Hassanein, K., Head, M., \&Ivanov, A. (2007). The role of social presence in establishing loyalty in e-Service environments. Interacting with Computers, 19(1), 43-56. 
International Journal of Business Information Systems Strategies (IJBISS) Vol.5, No.1,February 2016

13. De Cannière, M. H., De Pelsmacker, P., \&Geuens, M. (2009). Relationship quality and the theory of planned behavior models of behavioral intentions and purchase behavior. Journal of Business Research, 62(1), 82-92.

14. De Wulf, K., Odekerken-Schröder, G., \& Van Kenhove, P. (2003). Investments in consumer relationships: a critical reassessment and model extension. The International Review of Retail, Distribution and Consumer Research, 13(3), 245-261.

15. Dorsch, M. J., Swanson, S. R., \& Kelley, S. W. (1998). The role of relationship quality in the stratification of vendors as perceived by customers. Journal of the Academy of Marketing Science, 26(2), 128-142.

16. Eriksson, K., Kerem, K., \& Nilsson, D. (2005). Customer acceptance of internet banking in Estonia. International Journal of Bank Marketing, 23(2), 200-216.

17. Esmaeili, M., Nazarpoori, A., \&Najafi, M. (2013). An investigation on loyalty formation model in ebanking customers: A case study of banking industry. Management Science Letters, 3(3).

18. Floh, A., \&Treiblmaier, H. (2006). What keeps the e-banking customer loyal? A multigroup analysis of the moderating role of consumer characteristics on e-loyalty in the financial service industry. Journal of Electronic Commerce Research, 7(2), 97-110.

19. Fornell, C., \&Larcker, D. F. (1981). Evaluating structural equation models with unobservable variables and measurement error. Journal of marketing research, 18(1), 39-50.

20. Garbarino, E., \& Johnson, M. S. (1999). The different roles of satisfaction, trust, and commitment in customer relationships. the Journal of Marketing, 63(2), 70-87.

21. Gefen, D., Karahanna, E., \& Straub, D. W. (2003). Trust and TAM in online shopping: an integrated model. MIS quarterly, 27(1), 51-90.

22. Ghane, S., Fathian, M., Gholamian, M. R., Zbakh, M., El Kettani, M. D., Jambari, H., \& Chen, C. (2011). Full Relationship Among E-Satisfaction, E-Trust, E-Service Quality, and E-Loyalty: the case of Iran E-Banking. Journal of Theoretical and Applied Information Technology, 33(1), 1-6.

23. Gundlach, G. T., Achrol, R. S., \&Mentzer, J. T. (1995). The structure of commitment in exchange. The Journal of Marketing, 59(1), 78-92.

24. Hair, J.F. Jr, Black, C.W., Babin, J.B., Anderson, R.E. and Tatham, L.R. (2006), Multivariate Data Analysis, 6th ed., Pearson, Upper Saddle River, NJ.

25. Hennig-Thurau, T., \& Klee, A. (1997). The impact of customer satisfaction and relationship quality on customer retention: A critical reassessment and model development. Psychology \& Marketing, 14(8), 737-764.

26. Hennig-Thurau, T. (2000). Relationship quality and customer retention through strategic communication of customer skills. Journal of Marketing Management, 16(1-3), 55-79.

27. Hennig-Thurau, T., \& Hansen, U. (2000). Relationship marketing-some reflections on the state-ofthe-art of the relational concept. Relationship marketing: Gaining competitive advantage through customer satisfaction and customer retention, 3-27.

28. Järvenpää, S. L., Tractinsky, N., Saarinen, L., \& Vitale, M. (1999). Consumer trust in an Internet store: A cross-cultural validation. Journal of Computer-Mediated Communication, 5(2), 1-5.

29. Johnson, M. D., Herrmann, A., \& Huber, F. (2006). The evolution of loyalty intentions. Journal of Marketing, 70(2), 122-132.

30. Johnson, J. L., Sohi, R. S., \&Grewal, R. (2004). The role of relational knowledge stores in interfirm partnering. Journal of Marketing, 68(3), 21-36.

31. Kim, Y. J., Han, S. M., \& Lee, E. (2013). The role of trust in online shopping malls: different types of trust and how they affect consumer intention. International Journal of Electronic Commerce, 4(2). 385-388

32. Kesharwani, A., \&Bisht, S. S. (2012). The impact of trust and perceived risk on internet banking adoption in India: An extension of technology acceptance model. International Journal of Bank Marketing, 30(4), 303-322.

33. Lang, B., \& Colgate, M. (2003). Relationship quality, on-line banking and the information technology gap. International Journal of Bank Marketing, 21(1), 29-37.

34. Leonidou, L. C., Barnes, B. R., \&Talias, M. A. (2006). Exporter-importer relationship quality: The inhibiting role of uncertainty, distance, and conflict.Industrial Marketing Management, 35(5), 576588. 
International Journal of Business Information Systems Strategies (IJBISS) Vol.5, No.1,February 2016

35. Leuthesser, L., \&Kohli, A. K. (1995). Relational behavior in business markets: Iplications for relationship management. Journal of Business Research, 34(3), 221-233.

36. Liang, C. J., Chen, H. J., \& Wang, W. H. (2008). Does online relationship marketing enhance customer retention and cross-buying?. The service industries journal, 28(6), 769-787.

37. Liang, T. P., Ho, Y. T., Li, Y. W., \& Turban, E. (2011). What drives social commerce: The role of social support and relationship quality. International Journal of Electronic Commerce, 16(2), 69-90.

38. Lin, H. H., \& Wang, Y. S. (2006). An examination of the determinants of customer loyalty in mobile commerce contexts. Information \& Management, 43(3), 271-282.

39. Liu, C., Marchewka, J. T., Lu, J., \& Yu, C. S. (2004). Beyond concern: a privacy-trust-behavioral intention model of electronic commerce. Information \& Management, 42(1), 127-142.

40. Loureiro, S. M. C., Kaufmann, H. R., \&Rabino, S. (2014). Intentions to use and recommend to others: an empirical study of online banking practices in Portugal and Austria. Online Information Review, 38(2), 2-2.

41. Mayer, R. C., Davis, J. H., \&Schoorman, F. D. (1995). An integrative model of organizational trust. Academy of management review, 20(3), 709-734.

42. Meuter, M. L., Ostrom, A. L., Roundtree, R. I., \&Bitner, M. J. (2000). Self-service technologies: understanding customer satisfaction with technology-based service encounters. Journal of Marketing, 64(3), 50-64.

43. Moliner, M. A., Sánchez, J., Rodríguez, R. M., \&Callarisa, L. (2007). Relationship quality with a travel agency: The influence of the postpurchase perceived value of a tourism package. Tourism and Hospitality Research, 7(3-4), 194-211.

44. Mols, N. P. (1998). The Internet and the banks' strategic distribution channel decisions. Internet Research, 8(4), 331-337.

45. Moorman, C., Zaltman, G., \&Deshpande, R. (1992). Relationships Between Providers and Users of Market Research: The Dynamics of Trust. Journal of marketing research, 29(3), 314-28.

46. Mukherjee, A., \&Nath, P. (2003). A model of trust in online relationship banking. International Journal of Bank Marketing, 21(1), 5-15.

47. Ndubisi, N. O. (2007). Relationship quality antecedents: the Malaysian retail banking perspective. International Journal of Quality \& Reliability Management, 24(8), 829-845.

48. Nusair, K. K., \&Kandampully, J. (2008). The antecedents of customer satisfaction with online travel services: a conceptual model. European Business Review, 20(1), 4-19.

49. O'Cass, A., \& Grace, D. (2008). Understanding the role of retail store service in light of self-imagestore image congruence. Psychology \& Marketing, 25(6), 521-537.

50. Oliver, R.L. (1981). Measurement and evaluation of satisfaction processes in retail settings. Journal of Retailing, 57(3), 25-48.

51. Pikkarainen, T., Pikkarainen, K., Karjaluoto, H., \&Pahnila, S. (2004). Consumer acceptance of online banking: an extension of the technology acceptance model. Internet research, 14(3), 224-235.

52. Prasad, C. J., \&Aryasri, A. R. (2011). Effect of shopper attributes on retail format choice behaviour for food and grocery retailing in India. International Journal of Retail \& Distribution Management, 39(1), 68-86.

53. Rajaobelina, L., Brun, I., \&Toufaily, É. (2013). A relational classification of online banking customers. International Journal of Bank Marketing, 31(3), 187-205.

54. Ratnasingham, P. (1998). The importance of trust in electronic commerce. Internet research, 8(4), 313-321.

55. Rexha, N., Kingshott, R. P. J., \& Aw, A. S. S. (2003). The impact of the relational plan on adoption of electronic banking. Journal of Services Marketing, 17(1), 53-67.

56. Ritter, D. S. (1993). Relationship banking: cross-selling the bank's products \& services to meet your customer's every financial need. Bankers Publishing Company/Probus Publishing Company.

57. Smith, J. B. (1998). Buyer-seller relationships: similarity, relationship management, and quality. Psychology \& Marketing, 15(1), 3-21.

58. Storbacka, K., Strandvik, T., \&Grönroos, C. (1994). Managing customer relationships for profit: the dynamics of relationship quality. International journal of service industry management, 5(5), 21-38. 
International Journal of Business Information Systems Strategies (IJBISS) Vol.5, No.1,February 2016

59. Suh, B., \& Han, I. (2003). Effect of trust on customer acceptance of Internet banking. Electronic Commerce research and applications, 1(3), 247-263.

60. Taylor, S., \& Todd, P. A. (1995). Understanding information technology usage: A test of competing models. Information systems research, 6(2), 144-176.

61. Tripathi, G., \& Dave, K. (2013). Store format choice and relationship quality in apparel retail: A study of young and early-middle aged shoppers in New Delhi region. Journal of Retailing and Consumer Services, 20(5), 479-487.

62. Ulaga, W., \&Eggert, A. (2006). Relationship value and relationship quality: Broadening the nomological network of business-to-business relationships. European Journal of Marketing, 40(3/4), 311-327.

63. Van Bruggen, G. H., Kacker, M., \&Nieuwlaat, C. (2005). The impact of channel function performance on buyer-seller relationships in marketing channels.International Journal of Research in Marketing, 22(2), 141-158.

64. Walter, A., Müller, T. A., Helfert, G., \& Ritter, T. (2003). Functions of industrial supplier relationships and their impact on relationship quality. Industrial Marketing Management, 32(2), 159169.

65. Warrington, T. B., \& Caldwell, H. M. (2000). Building trust to develop competitive advantage in ebusiness relationships. Competitiveness Review: An International Business Journal incorporating Journal of Global Competitiveness, 10(2), 160-168.

66. Wong, A., \&Sohal, A. (2002). An examination of the relationship between trust, commitment and relationship quality. International Journal of Retail \& Distribution Management, 30(1), 34-50.

67. Yee, B. Y., \&Faziharudean, T. M. (2010). Factors affecting customer loyalty of using Internet banking in Malaysia. Journal of Electronic Banking Systems, 2010(2010), 21.

68. Yousafzai, S., Pallister, J., \&Foxall, G. (2009). Multi-dimensional role of trust in Internet banking adoption. The Service Industries Journal, 29(5), 591-605.

69. Zhang, Y., Fang, Y., Wei, K. K., Ramsey, E., McCole, P., \& Chen, H. (2011). Repurchase intention in b2c e-commerce-a relationship quality perspective.Information\& Management, 48(6), 192-200. 